\title{
EVELYN WAUGH'S WAR NOVELS IN FRANCOIST SPAIN
}

\begin{abstract}
Evelyn Waugh's experiences as captain in the Second World War represented the raw material for several novels, such as Put out More Flags (1942), Men at Arms (1952) and Brideshead Revisited (1945). These novels depict, on the one hand, the experiences of once immature bright young people who are now confronting the war reality, and, on the other, they satirize the military bureaucracy and portray the nostalgia for the conservative age of Catholic English nobility, which disappeared during the war. It could be assumed that these three novels might have been well received in Franco's Spain as the Catholic theme as well as Waugh's right-wing conservative beliefs could have influenced the censors' approval or disapproval. Thus, the present paper will analyse the reception in Spain of Put out More Flags, Men at Arms and Brideshead Revisited considering the reports enclosed in the censorship files guarded at AGA (General Archive of the Administration) in Alcalá de Henares, Madrid. These documents reveal that Waugh's novels were not easily approved by the Spanish censors during the Francoist dictatorship.
\end{abstract}

Keywords: Waugh; reception; censorship; Spain; Franco.

Evelyn Waugh (1903-1966) was one of the best English satirists of the twentieth century. Some of his outstanding satires include Decline and Fall (1928), Vile Bodies (1930), Black Mischief (1932), Scoop (1933), The Loved One (1948), and A Handful of Dust (1934). Waugh expressed his right-wing Catholic views in nonfiction books such as Edmund Campion (1935) and Robbery under Law (1939), and his travels to Malta, Constantinople, Cairo, Spain, Abyssinia, Mexico, and other places provided the raw material for his most important travel books, such as Labels (1930), Remote People (1931), Waugh in Abyssinia (1936), and A Tourist in Africa (1960). Put out More Flags (1942), Men at Arms (1952), and Brideshead Revisited (1945) are some of Waugh's war novels based on his military service

\footnotetext{
* Autonomous University of Madrid and Polytechnic University of Madrid; Spain.
} 
during World War II. Put out More Flags shows the evolution of Waugh's once bright young people, introduced in earlier novels like Vile Bodies and now faced with a chaotic reality at the beginning of World War II. Men at Arms is the first novel in the trilogy Sward of Honour (1961), which also includes Officers and Gentlemen (1955) and Unconditional Surrender (1961), two novels that never passed through the Spanish censorship apparatus. Finally, Brideshead Revisited was written when Waugh was on leave from the army in 1944. In this novel, whose main theme is the Catholic faith, Waugh adopts a more serious approach to life and nostalgically revives the greatness of Britain before the war.

The study of the reception of English literature in Spain has aroused great interest among academics. Some of the first studies on this subject were carried out by foreign scholars, such as Lisa E. Davis, who published the article "Oscar Wilde in Spain" in 1973 in the journal Comparative Literature. One of the first Spanish scholars to study the topic of reception was Julio César Santoyo from the University of León. In 1988, Santoyo published the article "Chaucer en España: ediciones, traducciones y estudios críticos" in Miscelánea: A Journal of English and American Studies. Alberto Lázaro of the University of Alcalá published a series of essays on the reception of Virginia Wolf, James Joyce and H.G. Wells in Spain. He also directed a three-year project on reception entitled: La recepción de la narrativa inglesa en la España del Siglo XX: ediciones, critica y censura. In the first decade of this century, Spanish scholars wrote numerous essays and chapters on the reception of British authors in Europe and published several books on the subject. More recently, the scholar Pilar Somacarrera led a research on the translation and reception of English Canadian literature in Spain. In 2013, she edited a collection of essays entitled Made in Canada, Read in Spain: Essays on the Translation and Circulation of English-Canadian Literature. Likewise, a number of dissertations have been written on the topic of reception, such as Traducción inglés-español y censura de textos narrativos en la España de Franco (1962-1969) by Marta Rioja Barrocal, presented at the University of León in 2008. Furthermore, in 2012, Monica Olivares Leyva defended her doctoral thesis at the University of Alcalá, entitled La recepción de Graham Greene en España.

In Spain, Men at Arms, Put out More Flags, and Brideshead Revisited have been studied by scholars such as Carlos Villar Flor, an expert on Waugh's work who analyses Waugh's novels in depth in his dissertation La caracterización como producto y como proceso en las novelas de Evelyn Waugh (1995). As for the reception of Waugh's writings in Spain, Villar Flor has a part of the translations of Waugh's 
novels into Spanish in the article "Spanish Translations of Works by Evelyn Waugh: 1943-2011" (2011), issued in Evelyn Waugh Newsletter and Studies, vol. 42. More recently, scholars such as Cristina Zimbroianu have published several articles on Waugh, e.g. "Las novelas de Evelyn Waugh en la España de Franco", published in 2017 in Sextas jornadas de jóvenes investigadores de la Universidad de Alcalá and "Evelyn Waugh's Decline and Fall and Vile Bodies in Franco's Spain and Communist Romania", published in 2019 in Philologica Canariensia. In addition, Professor Manuel Megías Rosa (1990) and journalists, such as Teresa Amiguet (2016), have reviewed, discussed, and debated Waugh's work, but none of them have taken an interest in Waugh's reception by the Spanish censors who decided which novels were allowed in the country during Franco's period. At first glance, one might think that these three novels had no difficulty in obtaining the approval of the Spanish censors to be put on the market. Therefore, this paper will analyse the reception of Put out More Flags, Men at Arms and Brideshead Revisited from the point of view of censorship during the Francoist government in order to determine whether or not the reception of these novels was conditioned by the censorship apparatus. The censorship files kept in the AGA (General Archive of the Administration) in Alcalá de Henares were consulted for this research.

\section{Censorship in Spain}

The methods of analysis in this study are informed by current debates about theories of reception that emphasise the social function of literature. Of the many critical positions within reception aesthetics, the model proposed by the German critic Hans Robert Jauss in his Toward an Aesthetic of Reception (1982) will guide this study of Waugh. The theory of reception suggested by Jauss is a response to the Marxist and formalist schools that restricted the role of readers and deprived literature of "the dimension of its reception and influence" (Jauss 18). Jauss's main interest is not in the reaction of an individual reader at a particular point in time, but in the changing, interpretive, and critical reactions of the general audience or informed reader over a period of time. These reactions are contained in the term 'horizon of expectation' which includes political and social factors necessary for the study of the reception of Put out More Flags, Men at Arms and Brideshead Revisited in Spain (25). The political factors are concerned with the historical background in Spain during the Francoist dictatorship on the one hand, and the social factors concerning the censors' reaction to Waugh's 
novels on the other.

The three novels reached Spain during the totalitarian Francoist regime (1936-1975), which may have made it difficult for foreign authors such as Evelyn Waugh to enter, as culture was controlled by censorship. The Ley de Prensa (Press Law) of 1938 aimed to control, on the one hand, press publications and, on the other, non-periodical publications such as books and other materials printed in Spain. Thus, on April 29, 1938, in Burgos, the Minister of the Interior, Ramón Serrano Suner, signed a decree that referred to the production of books, pamphlets and other printed materials (Boletín Oficial del Estado 7035). In the introductory section of this press law, Serrano Suñer made it clear that all nonperiodical materials were to be subject to censorship. He also stated that for economic reasons and because of the paper shortage, restrictive measures would be taken against foreign publications (Boletín Oficial del Estado 7035). The most important aspect of this law was the application of prior censorship. Thus, publishers were forced to submit to the censorship office two copies of the book they wished to circulate, as stated in article four:

Without the prior permission of the Ministry, the sale and distribution within the territory of the State of books, pamphlets and other printed material produced abroad shall be prohibited, irrespective of the language in which they are written. Publishers, booksellers or merchants who wish to sell such works must submit two copies for prior censorship. This norm applies to works sold or circulated in the national territory after July 17, 1936. A period of thirty days from the publication of this decree is granted for the fulfilment of this obligation. (Own translation Boletin Oficial de Estado 7036) ${ }^{7}$

Publishers could circulate only those books that met the conditions imposed by the regime and were favourably evaluated by the censors. Thus, in the first years of the Francoist dictatorship, publishers had to fill out a report that included the following information:

- The address of the publishing house;

- The presentation of two copies of the book to prior censorship;

\footnotetext{
${ }^{7}$ All translations are own translation, unless otherwise mentioned.
} 
- The name of the book's author;

- The title;

- The type of the printed material, in this case, a book;

- The character of the book, which could be literary, documentary, artistic and infantile;

- Political aspects;

- Number of pages; the number of copies and type of paper. (File 1641/1943)

All these details were attached to the report of the censors, which included some sections evaluating the works they read, such as: literary and artistic value, documentary value, political reference, deletion in case of approval, and other remarks (File 1641/1943). These sections were transformed into three questions around 1944:

1. Does it attack dogma or morality?

2. Does it attack the institutions of the regime?

3. Does it have literary or documentary value? (File 5554/44)

From about 1945 on, the censors' reports on the books included other questions, such as, "Does it attack dogma? The morals? The church and its ministers? The regime and its institutions? The persons who collaborated or collaborated with the regime? Do the objectionable passages qualify the entire content of the work?" (Abellán 19). This questionnaire was maintained until 1977, when the 1966 law was repealed.

In 1966, the Ley de Prensa e Imprenta (Law on Press and Printing) replaced prior censorship with voluntary consultation. This meant that publishers were free to voluntarily submit material to the censorship authority. In general, publishers preferred to practice voluntary consultation because they risked being punished by confiscation if the authorities discovered material considered dangerous to the regime, as mentioned in article 64:

When the administration becomes aware of a fact which may constitute an offense committed by the press or printing, it may, without prejudice to the obligation to report this immediately to the competent authorities and at the same time inform the Public Prosecutor's Office, order the seizure of the 
University of Bucharest Review $\propto$ Vol. X/2020, no. 1 (new series)

Re-writing, Re-imagining the Past (I)

criminal printing or publication at the disposal of the judicial authority. (Boletín Oficial del Estado 3314)

Seizure was often practiced by the censors because the Ministry of Information and Tourism (MIT) did not have a judicial cabinet that could present complaints to the prosecution. Therefore, the censor was responsible for assessing the illegal material and was obliged to report it to the competent authority (Boletín Oficial del Estado 3314).

The reception of Put out More Flags, Men at Arms and Brideshead Revisited in Spain

\section{Put out More Flags}

Put Out More Flags is Waugh's first novel about World War II, published in 1942. Waugh wrote the novel on his way home from Crete, where British troops were defeated by the Germans in 1941. In the 2012 Spanish edition, the translator Carlos Villar Flor mentions in the prologue that Waugh reflected on the demoralizing landscape of the Crete campaign and concluded that the British soldiers and officers acted incompetently and undignified (11). When the brigade was disbanded, Waugh returned to England aboard the ship Duchess of Richmond and wrote a draft of Put Out More Flags. In a letter he wrote in 1941 to Randolph Churchill, the son of Winston Churchill and Waugh's comrade-inarms, Waugh announced that he had just finished a novel dedicated to Randolph but that paper shortages would delay publication. Waugh was not correct in his prediction, for the novel was published in 1942.

Set in the Phoney War, the novel depicts the evolution of Waugh's once bright young people who are now confronted with a chaotic reality at the beginning of WWII. Thus, characters like Alaistair Trumpington, who was a hopeless student in Decline and Fall, has transformed into a serious young man who volunteers for the army. Similarly, Peter Pastmaster, the son of Margot Metroland, now shows a sense of responsibility by marrying and signing up for military service with the commandos. Another character, Ambrose Silk, becomes a homosexual half-Jewish intellectual who is on the run because he is accused of writing fascist propaganda. Basil Seal, already known from Black Mischief, had little interest in fighting, but rather in making some money from the war. However, with the intention of killing some Germans, Basil, Alastair and Peter joined a newly formed commando (Waugh 114). 
Put Out More Flags first reached Spain in 1947, when the censors reviewed an Argentine translation of the novel titled ;Más Banderas! On July 24, 1947, E.D.H.A.S.A. (Editora y Distribuidora Hispano Americana) requested permission to import the translation ¡Más Banderas! from Argentina in order to distribute three hundred copies in Spain at a price of 20 pesetas each. On August 25, 1947, the censorship authority refused the importation (File 3185/47). Unfortunately, the Censorship Board does not mention in its report the reason for its decision. Later, in 1962, the publisher Aguilar intended to include the novel in the collection Obras escogidas along with other novels such as Scoop, all of which were subject to censorship. The censor felt that ¡Más banderas! judged the generation that lived through World War I and the ghosts of the wartime environment, and he approved the novel (File 6545/62). Finally, Aguilar had not published this collection. Four years later, in 1966, Aguilar published the collection Novelas escogidas, but ¡Más banderas! was not included in it, although it had been previously approved.

On January 15, 1975, the publisher Alianza submitted the translation of Put Out More Flags from Horacio Laurora for voluntary consultation. Alianza included the novel in its "Libro de bolsillo" collection and published 10,000 copies. The censor gave a detailed review of the novel:

The action of the novel is set in the early months of World War II, specifically in England, where aristocratic society is suffering from the shocks of the outbreak of war. With great irony, the author depicts the void behaviour of these idle men, these discontented and deluded women, these domineering mothers with their Victorian life system, all of whom entered the ranks of the army without any professional effectiveness, led by untrained top officers [...] To avoid harsh criticism, the end of the novel shows a change in the thinking and behaviour of some of the previously mentioned characters. (File 504/75)

The report points out that on pages 77 and 206 of the translated version entitled ¡Más banderas! there are two references to Spain. On page 77, Spain is accused of "atrocities against left-wing intellectuals" (File 504/75):

'Geoffrey, when you say well known as a left-wing writer, do you suppose that if the fascists go into power here, I should be in their black list?' 'Yes 
certainly, my dear fellow.' 'They did frightful things to Left Wings Intellectuals in Spain.' Yes.' (Waugh 32)

And, on page 206 Spain is presented as a country without freedom (File 504/75):

'He's a most dangerous type. I know him well. He was living in Munich before the war- never out of the Brown House. 'That's as may be, but this isn't Spain. We can't go arresting people for what they say in a conversation in a café.' (Waugh 98)

The censors conclude that these two paragraphs were not to be censored because they were not unacceptable at the time they were written and because of their meaning (File 504/75). The novel was thus approved.

It is difficult to find an explanation for the initial rejection of the novel in 1947 and its subsequent acceptance in 1962 and 1975. It is possible that the novel was not accepted in 1947 precisely because of the political references already mentioned on pages 77 and 206. At that time, as Pegenaute explains, "any kind of pernicious idea, immoral concept or Marxist propaganda, anything which implies a disrespect for the dignity of our glorious army, any attack against the unity of our mother country, a disrespect for the Catholic religion or, in short, anything opposed to the meaning and goals of the Glorious Crusade" (qtd. in Rioja Barrocal n. pag.). On the other hand, the approval of the novel in 1962 and 1975 might have been influenced by the fact that in 1962 began a period of openness compared to the previous periods of the regime. As Rioja Barrocal explains, there were three elements that led to a certain loosening of censorship: "1) the rise of tourism; 2) the attempt to spread a positive image of Spain with the help of the advertising agency MacCann Ericsson (North American); and 3) Fraga's innovative creation of the new Press Law of 1966." (n. pag.)

\section{Men at Arms}

Men at Arms (1952) is Waugh's first novel in the war trilogy Sword of Honour (1965). The trilogy is based on Waugh's experiences during World War II, when he joined the Royal Marine and took part in an attack on Dakar in 1940. In 1941 he was transferred to Robert Laycock's Commando and fought in Crete. He then returned to the Marines. By 1934 he had completed parachute training as a member of Special Air Service Regiment and in 1944 went to Yugoslavia with 
University of Bucharest Review $\propto$ Vol. X/2020, no. 1 (new series)

Re-writing, Re-imagining the Past (I)

Randolph Churchill as part of Fitzroy Maclean Military Mission Tito's partisans (Heath 210). His difficult and gruff character brought Waugh into disfavour with his superiors, and he lost his adventurous spirit. He was never promoted as he deserved, and a turning point occurred in 1943 when Colonel Robert Laycock failed to keep its promise to include Waugh in the Hasky operation (North Africa) (Heath 211). Such experiences furthered Waugh's disdain for the army, as he mentioned in his diary:

I have got so bored with everything military that I can no longer remember the simplest details. I dislike the Army. I only want to get to work again. I do not want any more experiences in life "..." I don't want to be of service to anyone or anything. (Davie 547-8)

In Men at Arms Waugh introduces Guy Crouchback who belongs to an illustrious old family. When the war broke out, Guy was living in Italy, in a villa that belonged to his grandparents. Out of patriotic spirit and loneliness, having spent the last eight years alone since divorcing his unfaithful wife Virginia Santa Dulcina, Guy decided to enlist for the war, although it took countless applications before he was finally accepted into the Royal Corps halberdiers.

During Francoism, this novel reached the censorship board for the first and last time on February 24, 1955. The publisher Publicaciones Hispanoamericanas requested permission to import 150 copies of the novel from Buenos Aires, which was translated by Miguel Alfredo Olivera into Hombres en armas and published in Argentina by Emecé in 1954. On March 10, 1955, the censor refused to import the novel, without giving the reason for the refusal (File 1193/55). Unfortunately, no translations of this novel were recorded in Spain during the Francoist dictatorship. The other two novels in the war trilogy, Officers and Gentlemen (1955) and Unconditional Surrender (1961), had no more success than Men at Arms. The archives do not keep censorship files on these two novels, which means that they were not imported during the Franco period.

It is difficult to understand the censors' decision, but they may have banned the novel because there are passages in which Waugh puts Italian Fascism and German Nazism in a negative light. Guy Crouchback was still in Italy and reading his Italian newspaper when he expressed his opinion about fascist Italy and the Nazis: 
He lived too close to Fascism in Italy to share the opposing enthusiasm of his countrymen. He saw it neither as a calamity nor as a rebirth; as a rough improvisation merely "..." The German Nazi he knew to be mad and bad. Their participation dishonoured the cause of Spain, but the troubles to Bohemia, left him indifferent. (Waugh 3)

Waugh also emphasised that the British authorities were fighting the Fascists, an aspect that the Spanish censors would not approve, since Franco was not against the Fascists. Guy and his brother-in-law Box-Bender, who was a member of parliament, were investigated by the spy agency in London. BoxBender was not considered a threat, but Guy was accused of having good relations with the Fascist authorities in Italy. As a result, both Box-Bender and Guy were included in a "Most Secret Index" that became part of the "Most Secret Archives of the Second World War":

'Have we anything on this Box? Nothing very suspicious about a hyphenated name, I hope?' 'We've nothing very significant, sir "..."' ‘But Crouchback's quite another fish. Until September of last year he lived in Italy and is known to have been in good terms with Fascist authorities. Don't you think I would better open a file for him?' 'Yes, perhaps it would be as well'. 'For both sir?' 'Yes. Pop'em all in' “..." Thus, two new items were added to the Most Secret index, which later was micro-filmed and multiplied and dispersed into a dozen indexes in all the Counter Espionage Headquarters of the Free World and became a permanent part of the Most Secret archives of the Second World War. (91-2)

Such allusions might have been considered unacceptable by the censors precisely because the Italian Fascist and the Francoist dictatorships had several aspects in common (Rioja Berrocal n. pag.). For example, "both states tried to centralise things, they had a broad popular base, and both were chauvinistic. Both governments shared greetings, rhetoric, and aesthetics that praised these traditional and conservative dictatorships" (Rioja Berrocal n. pag.).

\section{Brideshead Revisited}

Brideshead Revisited, Waugh's most famous novel, was first published by Chapman and Hall in 1945. Waugh wrote the novel while on leave from the army 
in 1944, and he made the final corrections while doing his military service in Yugoslavia (Stannard 54). Waugh presents Charles Ryder, an architectural painter and infantry commander during World War II, travels to a new camp in Wiltshire and after a long time finds the site of Brideshead Castle. Charles nostalgically recalls his earlier experiences at Brideshead. The castle belongs to the Flyte family, whose members were Catholic and "half pagan," as the poet and translator Henry Reed called them in a review published in the New Statesman (1945: 408-9) on 23 June 1945. Sebastian Flyte, son of Alexander Flyte, Marquis of Marchmain, a young enthusiastic man suffering from alcoholism, becomes Charles's best friend. One of the causes of Sebastian's addiction was the separation of his parents after the end of the First World War, as Lord Marchmain refused to return to Brideshead. Instead, he went to Venice, where he met Cara, who accompanied him until his death. Eventually Sebastian ends up in a monastery where the monks take care of him. Charles marries Celia and falls in love with Julia Flyte, Sebastian's sister. Both Charles and Julia decide to divorce their spouses and marry each other. After the divorce, Julia's "half-pagan" father is blessed by the priest before he dies, and she decides that she will not marry Charles because she is forced to choose between Charles and God, and she chooses God. Eventually, Julia and her younger sister Cordelia enter WWII.

In addition to the Catholic theme, the novel also deals with certain aspects such as adultery, perversion, and drunkenness that could be considered immoral by the censors. Thus, on January 2, 1948, Manuel Quedo y Simón applied to the censorship board for permission to import the novel from Mexico under the title Evocación. The translation by E. T. Lawrence was originally published by Albatros in 1946. The novel was included in the collection "For Women" and the Spanish publisher intended to distribute 100 copies. The censorship file does not contain a report from the censor, but it does show that the novel was not approved (File 210/48). It is surprising that this edition was rejected, considering that the main theme is the Catholic religion, the pillar of Franco's government. Lord Marchmain, in his last days refused to go to church to receive the blessing of God, but he finally accepted God and the blessing of the Catholic priest. The Catholic faith, then, triumphed.

Nonetheless, the censor's refusal might be justified by the report published a few months later that year. On July 20, E.D.H.A.S.A. requested permission to import from Buenos Aires a translation entitled Retorno a Brideshead by Clara Diament. The publisher intended to distribute 150 copies at 36 pesetas each. The 
censor did not like the novel, but considered that it could be read by people "with elementary education" (File 3873/48):

This is a novel without a plot, which seems to be Protestant propaganda. I think it is unacceptable. A poorly translated novel that tells of the extravagances of an English aristocratic family that is Catholic in its own way. There are some attacks and allusions to the church $(41,64)$ uttered by one of the characters, and there are also some very realistic scenes. There are no serious flaws in the whole, and I do not think the novel is a danger to readers with an elementary education.

In the first scene that the censor considered an attack on the church, Charles receives some advice from his cousin Jasper to become successful at Oxford:

You'll find you spend half your second year shaking off the undesirable friends you made in your first.... Beware of the Anglo-Catholics - they're all sodomites with unpleasant accents. In fact, steer clear of all the religious groups; they do nothing but harm.... (Waugh 31)

In the second scene considered problematic, Charles is admonished by his cousin Jasper for being friends with Sebastian Flyte. Jasper explains to Charles that Sebastian's family is not an example to follow:

The Marchmains have lived apart since the war, you know. An extraordinary thing; everyone thought they were a devoted couple. Then he went off to France with his Yeomanry and just never came back. It was as if he'd been killed. She's a Roman Catholic, so she can't get a divorce - or won't, I expect. You can do anything at Rome with money, and they're enormously rich. Flyte may be all right, but Anthony Blanche - now there's a man there's absolutely no excuse for. (Waugh 46-7)

Even though the censor seemed not to enjoy the novel, he finally authorised the import on 7 August 1948.

In 1962, the publishing house Aguilar intended to publish Brideshead Revisited in the collection Obras Escogidas along with other works such as Decline and Fall, Scoop, Put Out More Flags, and Elena. The antecedent report of file 
6545/62 shows that the novel had already been approved in 1948. Nevertheless, Obras escogidas was not finally published. Aguilar published the collection Novelas escogidas in 1966 and submitted it to the Censorship Board in 1967. The precursor report for this novel, included in File 61/67, indicates that Retorno a Brideshead was approved in 1962 with deletions. It is not clear from this report which passages were deleted, and it is noted that the resolution of this novel was not mentioned in the file (File 61/67). In box 21/14290, which contains the files of the 1962 Obras escogidas, there is a copy of Retorno a Brideshead in the translation of Clara Diament, but no deletions could be found. Although the collection of novels Obras escogidas was not published in 1962, the Novelas escogidas of 1966, which included Retorno a Brideshead, were successful in Spain: 10,000 copies reached the reading public, whereas only 150 copies of Retorno a Brideshead were sold in the late 1940s.

Waugh's attack on the Church, noted by the censors in the report published in July 1948, may have initially influenced the censors' decision to reject the novel in January 1948. Luis Pegenaute clarifies that in the forties any attack on the Catholic faith and the Church was not allowed to be published. The moral values of the regime were based on Catholic doctrine; therefore, it was the job of the censors to preserve the ideological principles of the government (Pegenaute 89). The censors wanted to protect both the government and the Church "from a common enemy, anti-Spain. Anything remotely identifiable with 'foreignizing', secularism, Marxism, Freemasonry, etc., was to be proscribed" (Pegenaute 89). Waugh's attack on the Church was included in both editions, the one revised in January and the one revised in July, so the fact that the novel was originally rejected and then accepted after a few months is contradictory. However, this contradiction can be explained by the arbitrariness of the censorship system.

Looking at the reaction of the censors, first negative, then positive, one might conclude that Brideshead Revisited was subject to the arbitrariness of the censors. Pegenaute states that the censorship law did not prevent arbitrariness, which led to frequent contradictions. This means that works that were initially rejected were "accepted a few months later when a new application was made" (Pegenaute 91). Therefore, the rejection of Brideshead Revisited in January could have been caused by the bureaucracy of the Censorship Board, which led to arbitrariness. Abellán explains that the arbitrariness was completely hierarchical and referred to different levels. On the first level were the lectores (readers), who were officials with very little cultural background. At the second level were the 
dictaminadores (legal examiners), who negotiated with the writers, and were represented in the provinces by the head of the Editorial Office and the provincial delegate. The third level belonged to those responsible for censorship policy, who made the final decisions. At this level, it was almost impossible for authors and publishers to negotiate. These negotiations, Abellán makes clear, required a good network of friends and a certain personal prestige.

Even if the rejection and acceptance of Brideshead Revisited was the result of arbitrariness, it should also be taken into account the fact that the novel was eventually approved because, firstly, it was English and, secondly, it could be considered "popular" literature. Pegenaute points out that the attitude of the Francoist patronage towards English literature was quite positive, as the Minister of Education, José María Pemán y Pemartín, during Franco's early dictatorship, believed that the English novel was "charming, provides spiritual relief, and presents an effective inner moral life" (qtd. in Pegenaute 92). However, Pemartín was not referring to the novels of authors such as "Lawrence or Joyce, who are crude, morbid, sensual, and indecent, or those of Aldous Huxley, for even though he is extremely intelligent, his works are dangerously anarchic, nihilistic, and dilettante" (qtd. in Pegenaute 92).

Waugh is also "crude" and "morbid" in his early novels, but not in Brideshead Revisited. Rather, in Brideshead, he is as Pemartín liked: "gentle, realistic, and poetic at the same time" (qtd. in Pegenaute 92). He also appreciated English Victorian novels, including those by Thackeray or by the Bronte sisters, by George Eliot or Anthony Hope, because they are sometimes critical and develop the everyday family life and adventures of the British upper middle class (qtd. in Pegenaute 92). Thus, the only products offered to readers were "translations of 'inoffensive' foreign authors and the publications of those native writers favoured by patronage" (Pegenaute 93). "Inoffensive," according to Pegenaute, meant a particular culture of escaping reality "that reached a much larger audience than official culture." Pegenaute cites Carr and Fusi who point out that "such a culture allowed private interests to take advantage of a consumer culture that had no political or intellectual content and was therefore harmless" (93). This is why there were so many translations of "popular" literature such as love stories, thrillers, or detective novels during the first decade of the regime (Pegenaute 93). 


\section{Conclusions}

This study, based on Jauss's historical and social determinants that focus on the historical background against which Waugh's novels were received, concludes that the reception of Put out More Flags, Men at Arms and Brideshead Revisited in Spain during General Franco's dictatorship was negatively affected by the censorship authorities, as readers had limited access to Put out More Flags and Man at Arms in particular. Thus, Put out More Flags was initially rejected in 1947 and approved in 1975, when Franco's regime was about to end and censorship was more flexible. Another translation of this novel, entitled Izad más banderas, was not published until 2012 by Carlos Villar Flor. Men at Arms never reached Spanish readers during the Franco dictatorship, as it was rejected by the censors in 1955, and publishers showed no greater interest in this novel during the Franco era. A translation of Man at Arms entitled Hombres en armas was published twenty-eight years after Franco's time, in 2003, by Carlos Villar Flor. The most successful proved to be Brideshead Revisited, which was approved in 1948, 1962, and 1966, and reached thousands of readers in 1967. After the Francoist dictatorship, this novel was translated several times in Retorno a Brideshead, in 1982, 83, 87, 1990, 92, 93, 96, 98, 2008, 2010 and 2015. As for the reasons for the acceptance or rejection of these novels by the censors, it is clear that they were influenced, on the one hand, by the political and religious references mentioned in these books and, on the other hand, by arbitrariness and the bureaucratic system.

\section{Works Cited}

\section{Archival and Institutional sources:}

Archivo General de la Administración. Fechoría negra. Expediente 5554/44. Signatura 21/07495.

Archivo General de la Administración. Un puñado de polvo. Expediente 1641/43. Signatura 21/6848.

Archivo General de la Administración. Más banderas. Expediente 3185/47. Signatura 21/08039.

Archivo General de la Administración. Más banderas. Expediente 504/75. Signatura 73/04584.

Archivo General de la Administración. Hombres en armas. Expediente 1193/55. 
Signatura 21/11018.

Archivo General de la Administración. Evocación. Expediente 3873/48. Signatura 21/08400.

Archivo General de la Administración. Obras escogidas. Expediente 6545/62. Signatura 21/14290.

Archivo General de la Administración. Novelas escogidas. Expediente 61/67. Signatura 21/17817.

Boletín Oficial del Estado. Ley de Prensa, 1938, April 28 Boletin Oficial del Estado. Ley de Prensa e Imprenta, 1966, March 18.

\section{Other Sources:}

Abellán, Manuel. Censura y creación literaria en España (1939-1976) in Ediciones Península, 1980. Print.

Amiguet, Teresa. “¿Porqué nadie quería a Evelyn Waugh?” in La Vanguardia. April 10. Web.

$<$ https://www.lavanguardia.com/hemeroteca/20160408/40972695755/evelynwaugh-novelistas-inglaterra.html>

Davis, Lisa. "Oscar Wilde in Spain" in Comparative Literature XXV. Oregon: Duke University Press, 1973. Print.

Heath, Jeffrey. The Picturesque Prison. Evelyn Waugh and His Writing. Montreal: McGill-Queen's University Press, 1982. Print.

Jauss, Hans Robert. Toward an Aesthetic of Reception. Trans. Timothy Bahti. Minnesota: University of Minnesota Press, 1982. Print.

Lázaro Lafuente, Alberto. “The First Spanish Translation of Virginia Wolf's Time Passes: Facts, Mysteries and Conjectures" in The Gove: Working Paper in English Studies. Jaén: University of Jaén, 2003. Print.

---. "James Joyce's Encounters with Spanish Censorship, 1939-1966" in Joyce Studies Annual. New York: Fordham University, 2001. Print.

---. H.G. Wells en España: estudio de los expedientes de censura (1939-1978). Madrid: Vebum, 2004. Print.

Megías, Manuel Rosa. Imposture in Decline and Fall. Revista Alicantina de Estudios Ingleses. Alicante: University of Alicante, 1990. Print.

Olivares Leyva, Mónica. La recepción de Graham Greene en España (Doctoral Dissertation). Alcalá: Alcalá University, 2012. Print.

Pegenaute Rodríguez, Luis. "Censoring translation and Translation as 
Censorship: Spain under Franco" in Translation and the (RE)Location of Meaning: Selected Papers of the CETRA Chair Seminars in Translation Studies, 1994-96, 1999. Lovaina: Universidad Católica de Lovaina. Print.

Reed, Henry. "Brideshead Revisited". New Statesman, 1945. June 23. Print.

Rioja Barrocal, Marta. Traducción inglés-español y censura de textos narrativos en la España de Franco (1962-1969) (Doctoral Dissertation). León: University of León, 2008. Print.

---. “English-Spanish Translations and Censorship in Spain” in Intralinea. 2010. Web.<inTRAlinea. online translation journal $>$ Archive $>$ Vol. 12>

Santoyo, Julio César. “Chaucer en España: ediciones, traducciones y estudios críticos". Miscelánea: A Journal of English and American Studies. Zaragora: University of Zaragoza, 1988. Print.

Somacarrera, Pilar. Made in Canada, Read in Spain: Essays on the Translation and Circulation of English-Canadian Literature. London: Versita-de Greuter, 2013.

Villar Flor, Carlos. La caracterización como producto y como proceso en las novelas de Evelyn Waugh. (Doctoral dissertation). Logroño: Servicio de Publicaciones de la Universidad de La Rioja, 1995. Print.

---. "Spanish Translations of Works by Evelyn Waugh: 1943-2011" in Evelyn Waugh Newsletter and Studies, vol. 42, no. 1, 2011. Web.

$<\mathrm{http}$ ://specialcollections.le.ac.uk/cdm/compoundobject/collection/p16445coll12/i d/1518/rec/14>

Waugh, Evelyn. Decline and Fall. London: Chapman and Hall, 1928. Print.

---. Labels. London: Duckworth, 1930. Print.

---. Remote People. London: Duckworth, 1931. Print.

---. Black Mischief. London: Chapman and Hall, 1932. Print.

---. Scoop. London: Chapman and Hall, 1932. Print.

---. A Handful of Dust. London: Chapman and Hall, 1934. Print.

---. Edmund Campion. London: Longmans, 1935. Print.

---. Waugh in Abyssinia. London: Longmans, Green \& Co, 1936. Print.

---. Robbery Under Law. London: Chapman and Hall, 1939. Print.

---. Put Out More Flags. London: Chapman and Hall, 1942. Print.

---. Brideshead Revisited. London: Chapman and Hall, 1945. Print.

---. ¡Más banderas! Trans. Horacio Laurora. Buenos Aires: Sudamericana, 1947.

Print.

---. The Loved One. London: Chapman and Hall, 1948. Print.

---. Retorno a Brideshead. Trans. Clara Diament. Buenos Aires: Sudamericana, 
Re-writing, Re-imagining the Past (I)

1948. Print.

---. Retorno a Brideshead. Trans. Clara Diament. Madrid: Aguilar, 1966. Print.

---. Men at Arms. London: Chapman and Hall, 1952. Print.

---. Officers and Gentlemen. London: Chapman and Hall, 1955. Print.

---. Hombres en armas. Trans. Miguel Alfredo Olivera. Buenos Aires: Emecé, 1954.

Print.

---. A Tourist in Africa. London: Chapman and Hall, 1960. Print.

---. Unconditional Surrender. London: Chapman and Hall, 1961. Print.

---. Sword of Honour. London: Chapman and Hall, 1961. Print.

---. ¡Más banderas! Trans. Horacio Laurora. Madrid: Alianza, 1974. Print.

---. Hombres en armas. Trans. Carlos Villar Flor. Madrid: Cátedra, 2003. Print.

---. ¡Izad más banderas! Trans. Carlos Villar Flor. Barcelona: RBA, 2012. Print.

---. Brideshead Revisited: The Sacred and Profane Memories of Captain Charles Ryder. London: Penguin, 2012. Web. Kindle Version.

Zimbroianu, Cristina. "Las novelas de Evelyn Waugh en la España de Franco" in Sextas jornadas de jóvenes investigadores de la Universidad de Alcalá. Alcalá: University of Alcalá 2017. Print.

---. “Evelyn Waugh's Decline and Fall and Vile Bodies in Franco's Spain and Communist Romania" in Philologica Canariensia 25. Las Palmas de Gran Canaria: servicio de publicaciones y difusión científica, 2019. Web

<Vol. 25 (2019) | Philologica Canariensia (ulpgc.es)> 